\title{
Diagnosis, Structure, and In vitro Antimicrobial and Antifungal Evaluation of some Amino benzoic acids, derived Ligand Schiff base and their Mixed Complexes with $\mathrm{Cu}$ (II), $\mathrm{Hg}$ (II), $\mathrm{Mn}(\mathrm{II}), \mathrm{Ni}(\mathrm{II})$ and $\mathrm{Co}(\mathrm{II})$
}

\author{
REHAB KADHEM RAHEM AL-SHEMARY ${ }^{1 *}$, LEKAA KHALID ABDUL KAREM ${ }^{1}$ \\ and FAAZA HASEEN GHANIM \\ Department of Chemistry, College of Education for Pure Sciences, Ibn -Al-Haitham, \\ University of Baghdad, Adhamiyah, Baghdad,10001, Iraq. \\ Corresponding author E-mail: drrehabalshemary@gmail.com
}

http://dx.doi.org/10.13005/ojc/340263

(Received: October 05, 2017; Accepted: January 30, 2018)

\begin{abstract}
Innovative various Schiff bases and their $\mathrm{Co}(\mathrm{II}), \mathrm{Ni}(\mathrm{II})$ and $\mathrm{Cu}(\mathrm{II})$ and $\mathrm{Hg}(\mathrm{II})$ complexes made by the condensation of 4-amino antipyrine with derived aminobenzoic acid (2-aminobenzoic acid, 3-aminobenzoic acid, and 4-aminobenzoic acid) have been prepared by conventional approaches. These complexes were studied by magnetic sensibility analysis, FTIR spectra, and molar-conductance and elemental analysis. Analytical values appeared which the mixed-ligand complexes presented ratio about 2:1 (ligand: metal) with the chelation 4 or 6 . The prepared compounds offered a good effect on the organisms; bacteria Staphylococcus aurous, Escherichia coli and fungi $C$. albicans, $A$. niger. etc, the biological products signalize which the mixed complexes show objectively worthy performance compared to all the investigated bacterial strains, and generally the action order of the produced complexes has been characterized as $\mathrm{Ni}(\mathrm{II})>\mathrm{Cu}(\mathrm{II})>\mathrm{L}$.
\end{abstract}

Keywords: Schiff bases, 4-aminopyrine, Biological activity.

\section{INTRODUCTION}

Through the previous decades, Schiff base was the most significant ligand in the chemistry of the metal complexes to include donor atoms like nitrogen and others..$^{1-3}$ considering their great enforcements in the scope of bioorganic, synthetic organic and medical chemistry, there has been formidable attention in the composition of new bioactive amines and evolving effective processes for their derivatives. ${ }^{4-6}$ Derivatives of 4 -amino antipyrine are used as the opener organic intermediates for the preparation of biomolecules for synthetic purposes, possess important biological, catalytic activity and an efficient reagent in trace analysis of some metal cations. ${ }^{6-7}$ The

This is an 2 Open Access article licensed under a Creative Commons Attribution-NonCommercial-ShareAlike 4.0 International License (https://creativecommons.org/licenses/by-nc-sa/4.0/), which permits unrestricted NonCommercial use, distribution and reproduction in any medium, provided the original work is properly cited. 
coordinating properties of 4-aminoantipyrine have been amended to give new ligands composed by the reaction with ketones, carbazides, thiocarbazides, and aldehydes etc. ${ }^{8-10}$ such as anthranilic acid, vanillin, furfural and o-phenylene diamine. ${ }^{11-14}$ The chelation chemistry, biological efficacy and new structural lineaments of the Schiff bases have attracted attention. They are contain potential chelation positions about four with various chelating force also this can allow altitude to different linking and several stereo-chemical in their chelation complexes. ${ }^{15-17}$ In this research, we characterized the installation and description of and the mixed coordination complexes of the ligands (Schiff bases and 1,10-phenanthroline) with several metal ions.

\section{MATERIALS AND METHODS}

\section{Apparatus and reagents}

All reagents 4-aminoantipyrine, 2-aminobenzoic acid, 3-aminobenzoic acid, 4-aminobenzoic point out acid, nickel cobalt, mercury in addition to copper (II)chlorides were of Merck \& Co. results and utilized as provided ${ }^{13} \mathrm{C}$ and ${ }^{1} \mathrm{HNMR}$ spectra . Microanalytical data of the complexes had measured at Bruker specrospin ultra shield magnets $300 \mathrm{MHz}$ instruments. FTIR spectra was registered on a Shimadzu FTIR spectrophotometer 8300. UV/Vis spectra were noted on UV/Vis Varian UV-Cary-100 spectrophotometers. The chloride content registered by way (potentiometric titration) on 686-Titro Dosim A-Metrohm Processor-665/Swiss. Magnetic susceptibility measuring has acquired on the solid state using Bruker BM6 instrument. Micro analysis ( $\mathrm{C}, \mathrm{H}$ and $\mathrm{N} \%$ ) of the formed complexes had performed by means of C.H.N. Analyzer on Perkin Elmer 2400 sequence II. Dissolving details that evaluated in Gallen Kamp melting point apparatus were unmodified.

\section{Synthesis of ligands}

The ligands [A1], [A2] and [A3] were synthesis approving to the general technique displayed in (scheme 1,2 and 3). The[A1], [A2] and [A3] was synthesized bymixing an ethanolic solution $(15 \mathrm{~mL})$ of 4 -amino antipyrine $(0.203 \mathrm{~g}, 0.001 \mathrm{~m}$ mole) with $(0.012 \mathrm{~g}, 0.001 \mathrm{~m}$ mole) 2-aminobenzoic acid in the same volume of ethanol (four drops of glacial acetic acid have been added). This reaction has been subsequently refluxed with stirring for $8 \mathrm{~h}$ and the solution has been tolerable at room temperature to form [A1, A2 and A3].

For (A1) $\left(\mathrm{C}_{18} \mathrm{H}_{18} \mathrm{~N}_{4} \mathrm{O}_{2}\right) \quad$ Mwt: (322.36), Yield(78\%) : 66 : m.p.: $156^{\circ} \mathrm{C}$, Anal. Cal. (\%): C, 67.07; $\mathrm{H}, 5.63 ; \mathrm{N}, 17.38$, Found (\%): C, 66.71; H, 5.32; N, 17.11, IR $\left(\mathrm{KBr}, \mathrm{cm}^{-1}\right): 3423, v(\mathrm{OH})$; 3350, 3223, $v_{\text {ass }}(\mathrm{NH}) ; 3016,(\mathrm{C} \% \mathrm{H})_{\text {aromitici }} ; 2908,(\mathrm{C} \% \mathrm{H})_{\text {alphatic }} ; 1686,(\mathrm{C}=\mathrm{O})$; $1606,(\mathrm{C}=\mathrm{N})_{\mathrm{st}} ; 1529,(\mathrm{C}=\mathrm{C})_{\mathrm{st}}, \mathrm{UV}-\mathrm{Vis}\left(\mathrm{DMSO}, \lambda_{\max }\right.$ $\left.(\mathrm{nm})\left(\mathrm{cm}^{-1}\right)\right): 240(41666), 312(32051),{ }^{1} \mathrm{HNMR}$ (DMSO- $\left.\mathrm{d}_{6}, 300 \mathrm{MHZ}\right) \delta: 2.26,\left(\mathrm{~s}, 3 \mathrm{H}, \mathrm{CH}_{3}\right) ; 2.49$, $(\mathrm{s}, 6 \mathrm{H}, \mathrm{DMSO}) ; 3.38,\left(\mathrm{~s}, 3 \mathrm{H}, \mathrm{CH}_{3}\right) ; 5.17,(\mathrm{~s}, 2 \mathrm{H}$, $\left.\mathrm{NH}_{2}\right) ; 6.54-8.12,\left(\mathrm{~m}, 12 \mathrm{H} 8, \mathrm{C}_{6} \mathrm{H}_{5}\right) ; 12.85,(\mathrm{~s}, 1 \mathrm{H}$, $\mathrm{COOH}) \cdot{ }^{13} \mathrm{CNMR}(\mathrm{DMSO}, 75 \mathrm{MHZ}) \lambda: 9.14(\mathrm{~s}, \mathrm{C}-$ $\left.\mathrm{CH}_{3}\right) ; 33.7\left(\mathrm{~s}, \mathrm{~N}-\mathrm{CH}_{3}\right): 41.01$; (s, DMSO), $114.18(\mathrm{~s},=\mathrm{C}-\mathrm{N})$; 123.56-135.45 (m, $\left.\mathrm{C}_{6} \mathrm{H}_{5}\right) ; 151.17(\mathrm{~s}, \mathrm{C}=\mathrm{N}) ; 154.98$ $(\mathrm{s}, \mathrm{N}-\mathrm{C}=) ; 161.72(\mathrm{~s}, \mathrm{COOH})$<smiles>Cc1c(N)c(=O)n(-c2ccccc2)n1C</smiles><smiles>Nc1ccccc1C(=O)O</smiles><smiles>Cc1c(N)/c(=N/c2ccccc2C(=O)O)n(-c2ccccc2)n1C</smiles>

scheme 1

For (A2) $\left(\mathrm{C}_{18} \mathrm{H}_{18} \mathrm{~N}_{4} \mathrm{O}_{2}\right)$ Mwt: (322.36), Yield(\%): 89, Anal. Cal. (\%): C, 65.24; H, 5.78; N, 16.91, Found (\%): C, 63.67; H, 4.40; N, 9.21, IR $\left(\mathrm{KBr}, \mathrm{Cm}^{-1}\right): 3478, \mathrm{v}(\mathrm{O}-\mathrm{H}) ; 3327,3236, v_{\text {as. }}(\mathrm{NH}) ; 3075$,
$(\mathrm{C} \% \mathrm{H})_{\text {aromatic }} ; 2929,(\mathrm{C} \% \mathrm{H})_{\text {aliphatic }} ; 1660,(\mathrm{C}=\mathrm{O})_{\text {carboxylic }} ; 1576$, $(\mathrm{C}=\mathrm{N})_{\text {imine }} ; 1543,(\mathrm{C}=\mathrm{C})_{\text {aromatic }}, \mathrm{UV}-\mathrm{Vis}$ (DMSO, $\left.\delta_{\max }(\mathrm{nm})\left(\mathrm{cm}^{-1}\right)\right): 275(36363), 385$ (25839). ${ }^{1} \mathrm{HNMR}$ (DMSO- $\left.\mathrm{d}_{6}, 300 \mathrm{MHZ}\right): \delta: 2.26\left(\mathrm{~s}, 3 \mathrm{H}, \mathrm{CH}_{3}\right) ; 2.47$, 
(s,6H,DMSO);3.58 (s,3H, $\left.\mathrm{CH}_{3}\right) ; 5.47 \quad(\mathrm{~s}, 2 \mathrm{H}$, $\left.\mathrm{NH}_{2}\right) ; 6.14-8.02,\left(\mathrm{~m}, 12 \mathrm{H}, \mathrm{C}_{6} \mathrm{H}_{5}\right) ; 12.58,(\mathrm{~s}, 1 \mathrm{H}, \mathrm{OH})$ ${ }^{13} \mathrm{CNMR}(\mathrm{DMSO}, 75 \mathrm{MHZ}) \delta: 10.12\left(\mathrm{~s}, \mathrm{C}-\mathrm{CH}_{3}\right)$ ;33.7(s, N- $\left.\mathrm{CH}_{3}\right)$ :40.38; (s,DMSO), 114.18(s,=C-N); 123.56-149.97 (m, $\left.\mathrm{C}_{6} \mathrm{H}_{5}\right) ; 151.17(\mathrm{~s}, \mathrm{C}=\mathrm{N}) ; 154.26$ $(\mathrm{s}, \mathrm{N}-\mathrm{C}=) ; 161.89(\mathrm{~s}, \mathrm{COOH})$.<smiles>Cc1c(N)c(=O)n(-c2ccccc2)n1C</smiles><smiles>Nc1cccc(C(=O)O)c1</smiles>

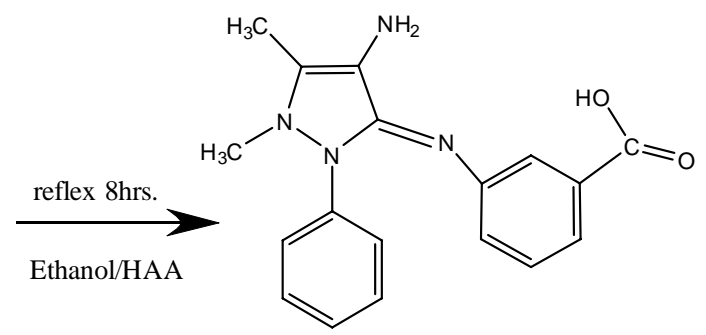

scheme 2
For (A3) $\left(\mathrm{C}_{18} \mathrm{H}_{18} \mathrm{~N}_{4} \mathrm{O}_{2}\right)$ Mwt: (322.36), Colour: (yellow) Yield(\%) : 85 : m.p.: $232^{\circ} \mathrm{C}$, Anal. Cal. (\%): C, 67.07; H, 5.63; N, 17.38, Found (\%): C, 67.97; H, 5.88; N, 17.69, IR $\left(\mathrm{KBr}, \quad \mathrm{cm}^{-1}\right): 3444$ $v(\mathrm{OH}) ; 3336,3215, v_{\mathrm{as}, \mathrm{s}}(\mathrm{NH}) ; 3051,(\mathrm{C} \% \mathrm{H})_{\text {aromatic }}$; $2970,(\mathrm{C} \% \mathrm{H})_{\text {aliphatic }} ; 1668,(\mathrm{C}=\mathrm{O})_{\text {carboxylic }} ; 1579(\mathrm{C}=\mathrm{N})$ imine $; 1566,(\mathrm{C}=\mathrm{C})$ aromatic, $\mathrm{UV}-\mathrm{Vis}$ (DMSO, $\delta_{\max }$ $(\mathrm{nm})\left(\mathrm{cm}^{-1}\right): 267$ (37453), 350(28571). ${ }^{1} \mathrm{HNMR}$
(DMSO- $\left.\mathrm{d}_{6}, 300 \mathrm{MHZ}\right): \lambda: 2.26\left(\mathrm{~s}, 3 \mathrm{H}, \mathrm{CH}_{3}\right) ; 2.47,(\mathrm{~s}, 6 \mathrm{H}$, DMSO); $3.11\left(\mathrm{~s}, 3 \mathrm{H}, \mathrm{CH}_{3}\right) ; 4.95\left(\mathrm{~s}, 2 \mathrm{H}, \mathrm{NH}_{2}\right) ; 6.5-8.12$, $\left(\mathrm{m}, 12 \mathrm{H}, \mathrm{C}_{6} \mathrm{H}_{5}\right) ; 12.83, \quad(\mathrm{~s}, 1 \mathrm{H}, \mathrm{OH}) .{ }^{13} \mathrm{C} \quad \mathrm{NMR}$ (DMSO,75MHZ) $\lambda: 10.12\left(\mathrm{~s}, \mathrm{C}-\mathrm{CH}_{3}\right) ; 33.7\left(\mathrm{~s}, \mathrm{~N}-\mathrm{CH}_{3}\right): 40.38$; (s,DMSO), 106.14 (s,=C-N); 123.56-149.97 $\left(\mathrm{m}, \mathrm{C}_{6} \mathrm{H}_{5}\right) ; 151.17$ (s,C=N);154.26 (s,N-C=); 165.64(s, $\mathrm{COOH})$.<smiles>Cc1c(N)c(=O)n(-c2ccccc2)n1C</smiles><smiles>Nc1ccc(C(=O)O)cc1</smiles><smiles>Cc1c(N)/c(=N/c2ccc(C(=O)O)cc2)n(-c2ccccc2)n1C</smiles>

scheme 3

\section{Syntheses of the mixed -complexes}

$(0.002 \mathrm{mmol}, 0.436) \mathrm{g}$ ligands [A1], [A2] and [A3] in $\mathrm{KOH}(0.001 \mathrm{mmol}, 0.056 \mathrm{~g})$ solution and metal salts $\left(0.340 \mathrm{~g} \mathrm{CuCl}_{2} .2 \mathrm{H}_{2} \mathrm{O}, 0.543 \mathrm{~g} \mathrm{HgCl}_{2}\right.$ $0.475 \mathrm{~g}, \mathrm{CoCl}_{2} .6 \mathrm{H}_{2} \mathrm{O}, 0.475 \mathrm{~g} \mathrm{NiCl}_{2} \cdot 6 \mathrm{H}_{2} \mathrm{O}$ and $\left.0.395 \mathrm{~g} \mathrm{MnCl}_{2} .4 \mathrm{H}_{2} \mathrm{O}\right)(0.001 \mathrm{mmol})$ with 1,10 phenanthroline $(0.001 \mathrm{mmol}, 0.18 \mathrm{~g})$ were dissolved in $(15 \mathrm{~mL})$ ethanol then for $1.5 \mathrm{~h}$ reflux the mixture. Then, the item was categorized at that point cleaned with (2:5) $\mathrm{mL}$ ethanol: diethyelther and dried at room temperature. At similar method were obtained the other complexes.

For $[\mathrm{Ni}(\mathrm{A} 1)(\mathrm{PHN}) \mathrm{Cl}]\left(\mathrm{C}_{30} \mathrm{H}_{25} \mathrm{CIN}_{6} \mathrm{NiO}_{2}\right)$ (S1);Mwt: (595.70), Yield(\%:68, m.p.: $267^{\circ} \mathrm{C}$,Anal. Cal. (\%): Ni, 9.85; C, 60.49; H, 4.23; N, 14.11; Cl, 12.52, Found (\%): Ni, 9.85; C, 60.49; $\mathrm{H}, 4.23 ; \mathrm{N}$, 19.67; $\mathrm{Cl}, 12.20$, IR $\left(\mathrm{KBr}, \mathrm{Cm}^{-1}\right): 34203,3352,\left(\mathrm{NH}_{2}\right)_{\mathrm{st}}$
$3021,(\mathrm{C} \% \mathrm{H})_{\text {aromitic }} ; 2927,(\mathrm{C} \% \mathrm{H})_{\text {alphatic }} ; 1545 v_{\text {asy }}$ $(\mathrm{COO}-) ; 1592,(\mathrm{C}=\mathrm{N})_{\mathrm{st}} ; 1518,(\mathrm{C}=\mathrm{C})_{\mathrm{st}} ; 1445 v_{\mathrm{sy}}$ (COO-) 565, (M\%N) st. UV-Vis (DMSO, $\delta_{\max }(\mathrm{nm})$ $\left.\left(\mathrm{cm}^{-1}\right)\right)$ :258, (38759); 292,(34246); 379, (26364); $656,(15242) ; 764,(13087)$, Molar conductance (DMSO): 8.9 S. $\mathrm{mol}^{-1} . \mathrm{cm}^{2}, \mu_{\mathrm{eff}}(\mathrm{BM}): 2.72$

For $[\mathrm{Cu}(\mathrm{A} 1)(\mathrm{PHN}) \mathrm{Cl}]\left(\mathrm{C}_{30} \mathrm{H}_{25} \mathrm{ClCuN}_{6} \mathrm{O}_{2}\right)$ (S2); Mwt: (600.56), Yield(\%): 77 , m.p.: $218^{\circ} \mathrm{C}$ Anal. Cal. (\%): $\mathrm{Cu}, 10.58 ; \mathrm{C}, 60.00 ; \mathrm{H}, 4.20 ; \mathrm{N}, 13.99 ; \mathrm{Cl}$, 5.90. Found (\%): $\mathrm{Cu}, 10.69 ; \mathrm{C}, 50.34 ; \mathrm{H}, 6.11 ; \mathrm{N}$, 19.17; $\mathrm{Cl}, 12.38 . \mathrm{IR}\left(\mathrm{KBr}, \mathrm{cm}^{-1}\right): 3478, \mathrm{v}(\mathrm{O}-\mathrm{H})$; $3424,3449,\left(\mathrm{NH}_{2}\right)_{\mathrm{st}} ; 3038,(\mathrm{C} \% \mathrm{H})_{\text {aromitic }} ; 2933$, $(\mathrm{C} \% \mathrm{H})_{\text {alphatic }} ; 1621,(\mathrm{C}=\mathrm{N})_{\text {st }} ; 1525, \mathrm{v}_{\text {asy. }}(\mathrm{COO}-)$ ;1516, $(\mathrm{C}=\mathrm{C})_{\mathrm{st}} ; 1417$, vs $(\mathrm{COO}-) ; 559,(\mathrm{M} \% \mathrm{~N})_{\mathrm{st}}$, UV-Vis (DMSO, $\left.\delta \max (\mathrm{nm})\left(\mathrm{cm}^{-1}\right)\right): 254,(39370)$; 286, (34965); 682,(14662).Molar conductance (DMSO): $10.2 \mathrm{~S} \cdot \mathrm{mol}^{-1} \cdot \mathrm{cm}^{2} \mu_{\mathrm{eff}}(\mathrm{BM}): 1.86$ 


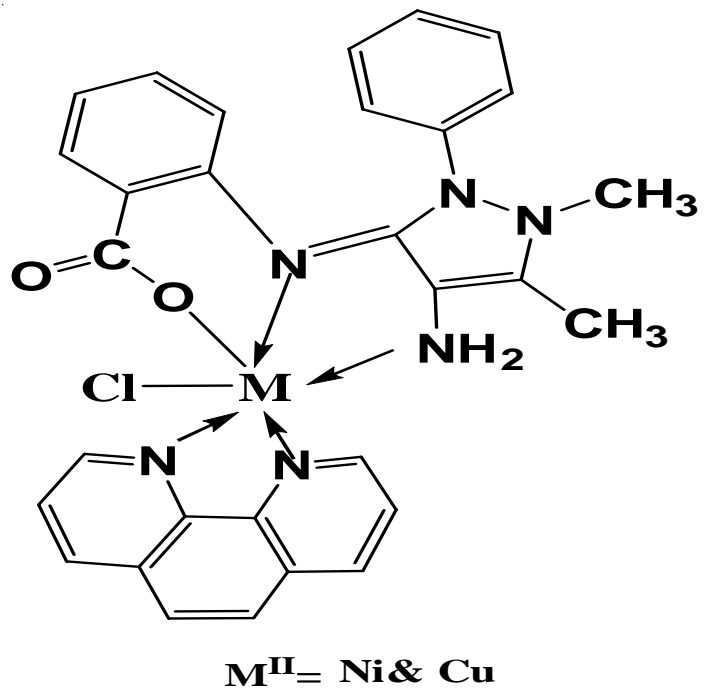

For $\left[\mathrm{Ni}(\mathrm{A} 2)(\mathrm{PHN}) \mathrm{Cl}_{2}\right]\left(\mathrm{C}_{30} \mathrm{H}_{26} \mathrm{Cl}_{2} \mathrm{~N}_{6} \mathrm{NiO}_{2}\right)$; Mwt: (632.17), Colour: (Greenish yellow), Yield(\%:68 , m.p.: $267^{\circ} \mathrm{C}$,Anal. Cal. (\%): Ni, 9.28; C, 57.00; H, 4.15; N, 13.29; Cl, 11.22, Found (\%): Ni, 10.23; C, $50.29 ; \mathrm{H}, 6.11 ; \mathrm{N}, 19.67 ; \mathrm{Cl}, 12.20$, IR $\left(\mathrm{KBr}, \mathrm{cm}^{-}\right.$ 1):3464,v(O-H); 3420, $3352,\left(\mathrm{NH}_{2}\right)$ st: 3096, $(\mathrm{C} \% \mathrm{H})_{\text {aromitic }} ; 2835,(\mathrm{C} \% \mathrm{H})_{\text {alphatic }} ; 1705,(\mathrm{C}=\mathrm{O})_{\text {st }}$; $16201590(\mathrm{C}=\mathrm{N})_{\mathrm{st}} 1618,(\mathrm{C}=\mathrm{C})_{\mathrm{st}} ; 565,(\mathrm{M} \% \mathrm{~N})_{\mathrm{st}}$, UV-Vis (DMSO, $\left.\delta_{\text {max }}(\mathrm{nm})\left(\mathrm{cm}^{-1}\right)\right)$ : 258, (38759); 292, (34246); 379, (26364); 656, (15242); 764, (13087),Molar conductance (DMSO): 8.9 S. mol ${ }^{-1}$. $\mathrm{cm}^{2}, \mu_{\text {eff }}(\mathrm{BM}): 2.72$

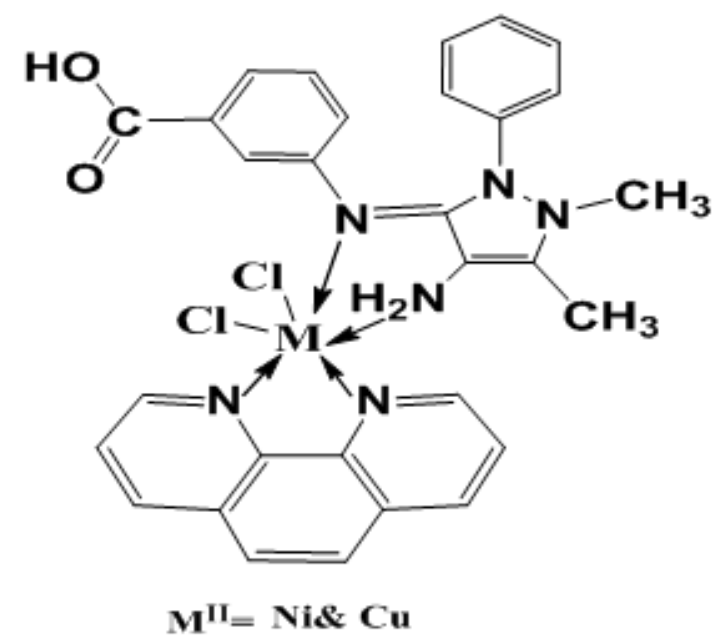

For $\left[\mathrm{Ni}(\mathrm{A} 3)(\mathrm{PHN}) \mathrm{Cl}_{2}\right]\left(\mathrm{C}_{30} \mathrm{H}_{26} \mathrm{~N}_{6} \mathrm{Cl}_{2} \mathrm{NiO}_{2}\right)$ (S5); Mwt: (632.17), Yield(\%:70, m.p.: $218^{\circ} \mathrm{C}$,Anal. Cal. (\%): Ni, 9.28; C, 57.67; H, 4.15; N, 13.29; Cl,

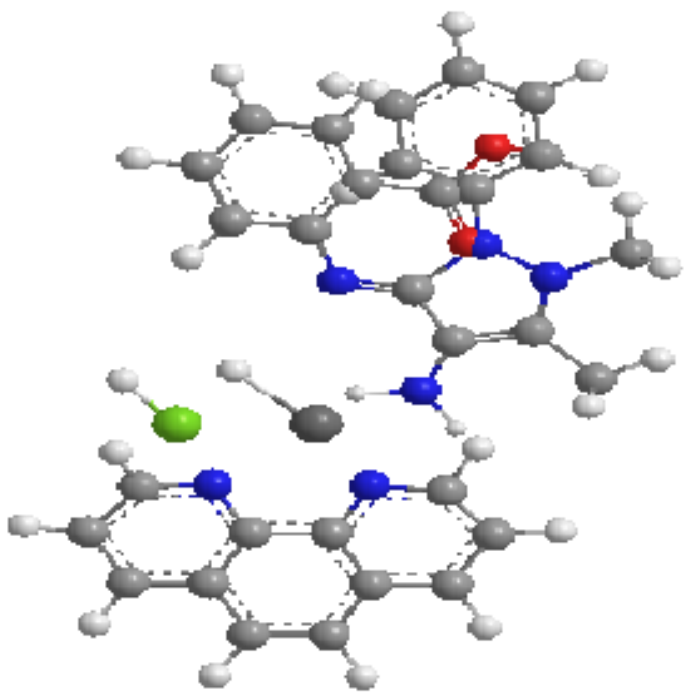

For $\left[\mathrm{Cu}(\mathrm{A} 2)(\mathrm{PHN}) \mathrm{Cl}_{2}\right]\left(\mathrm{C}_{30} \mathrm{H}_{26} \mathrm{Cl}_{2} \mathrm{CuN}_{6} \mathrm{O}_{2}\right)$ (S4); Mwt: (637.02), Yield(\%):77, m.p.: $218^{\circ} \mathrm{C}$ Anal. Cal. (\%): $\mathrm{Cu}, 9.98 ; \mathrm{C}, 56.56 ; \mathrm{H}, 4.11 ; \mathrm{N}, 13.19$; $\mathrm{Cl}$, 11.13. Found (\%): $\mathrm{Cu}, 10.69 ; \mathrm{C}, 50.34 ; \mathrm{H}, 6.11 ; \mathrm{N}$, 19.17; $\mathrm{Cl}, 12.38 . \mathrm{IR}\left(\mathrm{KBr}, \mathrm{cm}^{-1}\right) 3481, \mathrm{v}(\mathrm{O}-\mathrm{H})$; 3429, $3368\left(\mathrm{NH}_{2}\right)_{\mathrm{st}} ; 3062,(\mathrm{C} \% \mathrm{H})_{\text {aromitic }} ; 2923,(\mathrm{C} \% \mathrm{H})_{\text {alphatic }}$ $1621,(\mathrm{C}=\mathrm{O})_{\text {asymm }} ; 1585(\mathrm{C}=\mathrm{N})_{\text {st }} 1421,(\mathrm{C}=\mathrm{O})_{\text {symm }}$; 1585, $(\mathrm{C}=\mathrm{C})_{\mathrm{st}} ; 1171,(\mathrm{C}-\mathrm{O})_{\mathrm{st}} 523,438(\mathrm{M} \% \mathrm{~N})_{\mathrm{st}}$, UV-Vis (DMSO, $\left.\delta \max (\mathrm{nm})\left(\mathrm{cm}^{-1}\right)\right)$ : 254, (39370); 286, (34965); 413, (24213); 982, (10176).Molar conductance (DMSO): $10.2 \mathrm{~S} . \mathrm{mol}^{-1} \cdot \mathrm{cm}^{2} \mu_{\mathrm{eff}}(\mathrm{BM}): 1.68$

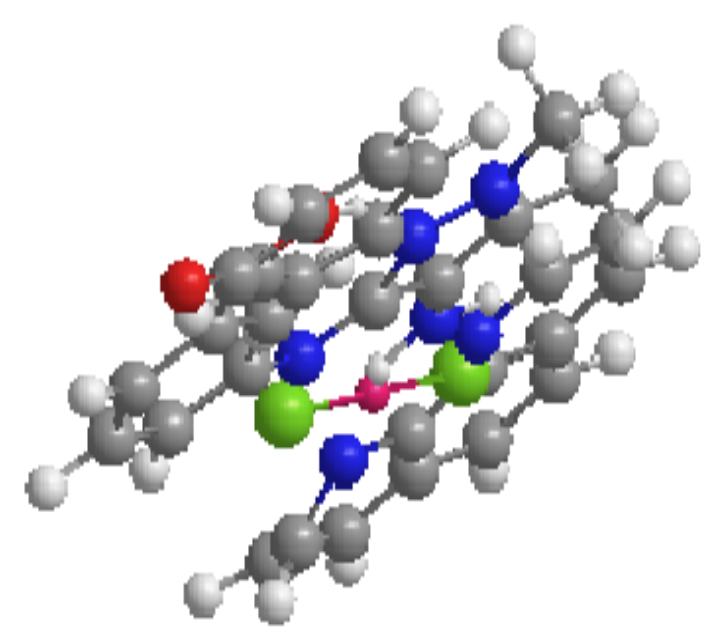

11.22,.Found (\%): Ni, 9.56; C, 57.88; H, 4.34; N, 13.28; $\mathrm{Cl}, 11.56, \mathrm{IR}\left(\mathrm{KBr}, \mathrm{cm}^{-1}\right): 3458, \mathrm{v}(\mathrm{O}-\mathrm{H})$; 3420, 3352 $,\left(\mathrm{NH}_{2}\right)_{\text {st; }} 3021,(\mathrm{C} \% \mathrm{H})_{\text {aromitic }} ; 2927,(\mathrm{C} \% \mathrm{H})_{\text {alphatic }}$; 
1624, $(\mathrm{C}=\mathrm{N})_{\mathrm{st}} ; 1618,(\mathrm{C}=\mathrm{C})_{\mathrm{st}} ; 565,(\mathrm{M} \% \mathrm{~N})_{\mathrm{st}}$ UV-Vis (DMSO, $\left.\delta_{\text {max }}(\mathrm{nm})\left(\mathrm{cm}^{-1}\right)\right)$ : 258, (38759); 292, (34246); 775, (12893),Molar conductance (DMSO): $8.9 \mathrm{~S}$. $\mathrm{mol}^{-1} \cdot \mathrm{cm}^{2}, \mu_{\mathrm{eff}}(\mathrm{BM})$ : Dia

For $\left[\mathrm{Cu}(\mathrm{A} 3)(\mathrm{PHN}) \mathrm{Cl}_{2}\right]\left(\mathrm{C}_{30} \mathrm{H}_{26} \mathrm{CuN}_{6} \mathrm{O}_{2}\right)$ (S6); Mwt: (566.11), Colour: (Green), Yield(\%) : 77 , m.p.: $218^{\circ} \mathrm{C}$ Anal. Cal. (\%): Cu, 11.22; C, 63.65; H,

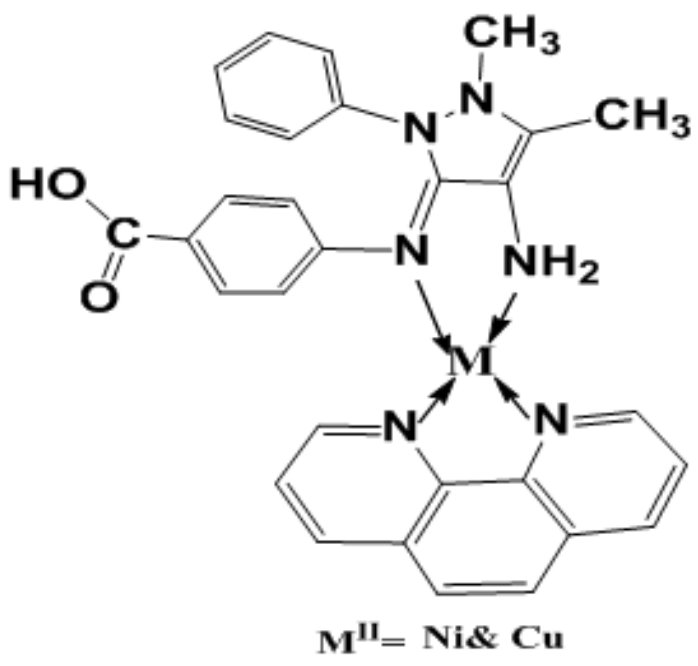

\section{Biological studies}

The organic action (In vitro) of selected compounds was screened with two bacteria Staphylococcus aureus and Escherichia coli by disc expansion way by means of nutrient agar as the environment and control as streptomycin. Also the antifungal efficacy of the components was screened by the same previous way in the environment as potato dextrose agar with the fungi $A$. niger and C. albicans. All the components have been in the (25, 50 and $100 \mathrm{ppm})$ concentrations of DMSO solutions that have synthesized disjointedly. A well was got on agarenvironment in the cultivated micro organism in a typical procedure. It was loaded with the screen solution utilizing plate and a micropipette the was brood for bacteria at $24 \mathrm{~h}, 37^{\circ} \mathrm{C}$ and for fungi at $72 \mathrm{~h} 30{ }^{\circ} \mathrm{C}$. Investigational solution was growth and suffused of the inoculated micro organism was influenced during this interval. The inhibition region advanced, at that was noted the concentration.

\section{IR spectra}

IR spectra of the Ligands and mixed compounds obviously point out the bonding
4.63; N, 14.85. Found (\%): $\mathrm{Cu}, 10.69 ; \mathrm{C}, 50.34 ; \mathrm{H}$, 6.11; N, 19.17. IR $\left(\mathrm{KBr}, \mathrm{cm}^{-1}\right): 3476, \mathrm{v}(\mathrm{O}-\mathrm{H}) ; 3424$, $3449,\left(\mathrm{NH}_{2}\right)_{\mathrm{st}} ; 3038,(\mathrm{C} \% \mathrm{H})_{\text {aromitic }} ; 2933,(\mathrm{C} \% \mathrm{H})_{\text {alphatic }}$; 1621, $(\mathrm{C}=\mathrm{O})_{\mathrm{st}}$ 1621, $(\mathrm{C}=\mathrm{N})_{\mathrm{st}} ; 1516,(\mathrm{C}=\mathrm{C})_{\mathrm{st}} ; 559$, $(\mathrm{M} \% \mathrm{~N})_{\mathrm{st}}, \mathrm{UV}-\mathrm{Vis}\left(\mathrm{DMSO}, \delta \max (\mathrm{nm})\left(\mathrm{cm}^{-1}\right)\right): 254$, (39370); 286, (34965); 543,(18416) . Molar conductance (DMSO): 10.2 S. $\mathrm{mol}^{-1} \cdot \mathrm{cm}^{2}, \mu_{\text {eff }}(\mathrm{BM})$ : 1.78

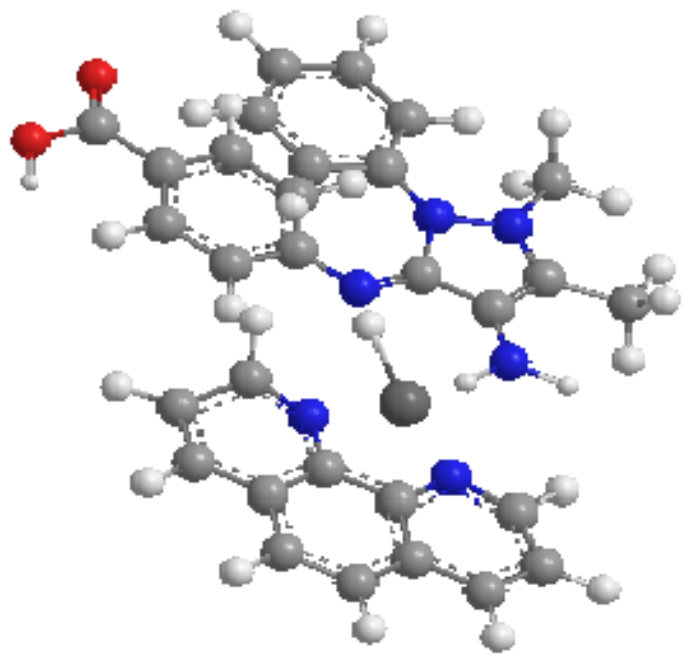

combination of the shift base ligands with metallic ion. A wide spectrum at $3423 \mathrm{~cm}^{-1}, 3478 \mathrm{~cm}^{-1}$ and $3444 \mathrm{~cm}^{-1}$ owing to $v(\mathrm{OH})$ stretching vibration for $\mathrm{Al}, \mathrm{A} 2$, and $\mathrm{A} 3$, respectively, $v_{\text {asym, sym }} \mathrm{NH}_{2}$ stretching vibration for $\mathrm{Al}, \mathrm{A} 2$, and $\mathrm{A} 3$, respectively. Also, they showed at 1636 while this band was disappeared in the spectrum of its mixed complexes for A1. In addition displayed at $(3358,3223) \mathrm{cm}^{-1}$, $(3327,3236) \mathrm{cm}^{-1}$, and $(3336,3215)$ characteristics of thestretching mode (azomethine) $(\mathrm{C}=\mathrm{N})$ suggesting the forming of the ligand results. This frequency was moved to lower value in the spectrum of its metal complexes (1581-1565 $\mathrm{cm}^{-1}$ ) liken with the ligand signalizing the partnership of the nitrogen of azomethine in coordination with metal ion. The chelation of nitrogen to the metallic ion could be prospective to lessen the electron density of the imine connection and consequently triggered a change in the group of $(\mathrm{C}=\mathrm{N})$. The penetrating bands at $1686 \mathrm{~cm}^{-1}, 1668 \mathrm{~cm}^{-1}$ and $1660 \mathrm{~cm}^{-1}$ shows in the IR spectra of the free ligands $A I, A 2$, and $A 3$ may be allocated to the $v(C=O)$ (carboxylic cluster). On the other hand, all spectra compounds forAl have stated the nonappearance of the characteristic band with the presence of dual characteristic bands 
at $1545-1525$ and $1445-1417 \mathrm{~cm}^{-1}$ related to $v_{\text {asy. }}$ (COO) in addition to $v_{\text {sy. }}\left(\mathrm{COO}^{-}\right)$correspondingly, $\left(\Delta v\left(\mathrm{COO}^{\prime \prime}\right)=v_{\mathrm{sy}} \cdot\left(\mathrm{COO}^{\prime}\right)-\mathrm{vs}_{\mathrm{ay}} \cdot(\mathrm{COO})\right)$ in range (108-100) $\mathrm{cm}^{-1}$, indicated the involvement of deprotonated group of $(\mathrm{COOH})$ in bonding and an organization of metallic ions through oxygen atoms of carboxyl groups signifying the contribution of the carboxylate oxygen atom in the compound structure. Decisive indication of the bonding was similarly has exposed noticeably that innovative bands in all metal complex spectrums in the small frequency regions at 548-531 and $483-465 \mathrm{~cm}^{-1}$ present to $v(\mathrm{M}-\mathrm{O})$ and $v(\mathrm{M}-\mathrm{N})$ extending frequencies, separately, which weren't appeared in the spectrum of ligands.

\section{Electronic spectra}

UV-Vis of [A1], [A2] and [A3] ligands spectra and the mixed-complexes were determined in solution of DMSO. Each compound was displayed huge energy band in the range $4166-36363 \mathrm{~cm}^{-1}$. This can be assigned to the L.F band. Also, the high energy absorption band in 25839-34965 $\mathrm{cm}^{-1}$ range. This can be assigned to the C.T band. The (S1) complex spectrum displayed three $\mathrm{d}$-d transition bands at 26364, 15242 and $13087 \mathrm{~cm}^{-1}$ that is due to ${ }^{3} \mathrm{~A}_{2} \mathrm{~g}_{(\mathrm{F})} \rightarrow{ }^{3} \mathrm{~T}_{1} \mathrm{~g}_{(\mathrm{F})},{ }^{3} \mathrm{~A}_{2} \mathrm{~g}_{(\mathrm{F})} \rightarrow{ }^{3} \mathrm{~T}_{2} \mathrm{~g}_{(\mathrm{F})}$ and ${ }^{3} \mathrm{~A}_{2} \mathrm{~g}_{(\mathrm{F})} \rightarrow{ }^{3} \mathrm{~T}_{1} \mathrm{~g}_{(\mathrm{P})}$ arrangements, individually, distinguishing of an octahedral arrangement. This arrangement has been moreover confirmed by its magnetically sensibility data (2.72IB)

The complex (S2) spectrum showed the $d-d$ bands at $14662 \mathrm{~cm}^{-1}$. This corresponds to ${ }^{2} \mathrm{Eg}_{(\mathrm{F})} \rightarrow{ }^{2} \mathrm{~T}_{2} \mathrm{~g}_{(\mathrm{F})}$ transition. The $\mathrm{d}-\mathrm{d}$ transition facilitates an unrecognizable octahedral arrangement in the area metal. Accordingly, the design is more confirmed by its magnetically susceptibility magnitude (1.86 IB).

The complex (S3) spectrum presented dual $d$-d transition bands in 15242 region, and $13087 \mathrm{~cm}$ that are given to ${ }^{3} \mathrm{~A}_{2} \mathrm{~g}_{(\mathrm{F})} \rightarrow{ }^{3} \mathrm{~T}_{1} \mathrm{~g}_{(\mathrm{P})}$ and ${ }^{3} \mathrm{~A}_{2} \mathrm{~g}_{(\mathrm{F})} \rightarrow{ }^{3} \mathrm{~T}_{1} \mathrm{~g}_{(\mathrm{F})}$ transitions, correspondingly. These transitions characterize the octahedral structure of the compound, that is as well confirmed by its magnetically susceptibility magnitude $(4.45 \mathrm{IB})$. The absorption spectrum of the complex (S4) presented the $d-d$ bands at $14662 \mathrm{~cm}^{-1}$. This corresponds to ${ }^{2} \mathrm{Eg}_{(\mathrm{F})} \rightarrow{ }^{2} \mathrm{~T}_{2} \mathrm{~g}_{(\mathrm{F})}$ transition. This $\mathrm{d}-\mathrm{d}$ transition has an inaccurate octahedral arrangement in the metal. This structure is additionally reinforced by its magnetic susceptibility data (1.86 IB).

The spectrum of complex (S5) of the displayed one d-d transition band at $12893 \mathrm{~cm}^{-1}$ that belong to ${ }^{1} \mathrm{~A}_{1} \mathrm{~g}_{(\mathrm{F})} \rightarrow{ }^{2} \mathrm{Eg}$ transition. The transition corresponds to a square planar of the compound geometry that is likewise confirmed by its diamagnetic susceptibility. The absorption spectrum of the complex (S6) presented the $d-d$ bands at $18416 \mathrm{~cm}^{-1}$. This corresponds to ${ }^{2} \mathrm{~B}_{19} \rightarrow{ }^{2} \mathrm{~A}_{1 \mathrm{~g}}$ transition. This $d-d$ transition has a square $2 \mathrm{D}$ arrangement. This structure is then confirmed by its magnetic susceptibility data (1.78 IB).

\section{NMR spectra}

${ }^{1}$ HNMR spectrum of Schiff base [A1] (in DMSO-d6 as solvent), showed a singlet signal at $\delta 2.26 \mathrm{ppm}$ for three protons of $\mathrm{CH}_{3}$ group, singlet signal at 2.49ppm for 6 protons for DMSO, a singlet signal at $\delta 3.38 \mathrm{ppm}$ for three protons of $\mathrm{CH}_{3}$ group, milt signals in range $\delta(6.54-8.12) \mathrm{ppm}$ that might be due to the twelve aromatic protons of phenyl rings. And two protons at $\mathrm{NH}_{2}$ of amine group gives as a broad singlet signal at $\delta 5.17 \mathrm{ppm}$. Finally, singlet signal at $\delta(12.85) \mathrm{ppm}$ concerning one proton of $\mathrm{OH}$ carboxylic group.

${ }^{1}$ HNMR spectrum of Schiff base [A2] (in DMSO- $d_{6}$ as solvent), showed a singlet signal at $\delta 2.26 \mathrm{ppm}$ for three protons of $\mathrm{CH}_{3}$ group, a singlet signal at $2.47 \mathrm{ppm}$ for 6 protons for DMSO, also singlet signal at $\delta 3.58 \mathrm{ppm}$ for three protons of $\mathrm{CH}_{3}$ group, milt signals in range $\delta(6.14-8.02) \mathrm{ppm}$ that might be due to the twelve aromatic protons of phenyl rings, and two protons at $\mathrm{NH}_{2}$ of amine group gives as a broad singlet signal at $\delta 4.47 \mathrm{ppm}$. Finally, a singlet signal at $\delta(12.58) p p m$ relating to one proton of $\mathrm{OH}$ carboxylic cluster.

${ }^{1}$ HNMR bands of Schiff base [A3] (in DMSO-d6 as solvent), Fig. (9) showed a singlet signal at $\delta 2.26 \mathrm{ppm}$ for three protons of $\mathrm{CH}_{3}$ group, singlet signal at $2.47 \mathrm{ppm}$ for 6 protons for DMSO, a singlet signal at $\delta 3.11 \mathrm{ppm}$ for three protons of $\mathrm{CH}_{3}$ group, milt signals in range $\delta(6.5-8.12) \mathrm{ppm}$ that might be due to the twelve aromatic protons of phenyl rings, and two protons at $\mathrm{NH}_{2}$ of amine group gives as a broad singlet signal at $84.95 \mathrm{ppm}$. Finally, a single signal at $\delta(12.83)$ ppm for carboxylic proton 
The ${ }^{13} \mathrm{CNMR}$ ligand $(\mathrm{A} 1)$ band displayed the $\mathrm{CH}_{3}-\mathrm{C}=$ group as the signal at $9.12 \mathrm{ppm}$ and $\mathrm{CH}_{3}-\mathrm{N}=$ group at 33.85 ppmgroup. Also, the peak of $(=\mathrm{C}-\mathrm{N})$ group showed at $105.18 \mathrm{ppm}$. The other peaks of aromatic carbons resonance observed at 122.70-149.97 ppm. The signals at $151.17 \mathrm{ppm}$. The other peaks of aromatic carbons resonance observed at 123.57-149.97ppm. Also, the peak of carboxylic carbon is displayed at 165.27 .

The ${ }^{13} \mathrm{CNMR}$ ligand (A2) spectrum displayed the $\mathrm{CH}_{3}-\mathrm{C}=$ group as the signal at 10.12 ppm and $\mathrm{CH}_{3}-\mathrm{N}=$ group at 33.85 ppmgroup iminic carbon $(\mathrm{C}=\mathrm{N})$ as functional group signal at 106.08 ppm. The other peaks of aromatic carbons resonance observed at 123.57-149.97 ppm. Also the peak of $10.12\left(\mathrm{~s}, \mathrm{C}-\mathrm{CH}_{3}\right) ; 33.7$ $\left(\mathrm{s}, \mathrm{N}-\mathrm{CH}_{3}\right)$ :40.38; (s, DMSO), $106.14(\mathrm{~s},=\mathrm{C}-\mathrm{N})$; 123.56-149.97 (m, $\left.\mathrm{C}_{6} \mathrm{H}_{5}\right) ; 151.17(\mathrm{~s}, \mathrm{C}=\mathrm{N}) ; 154.26$ (s,N-C=); 165.64(s, COOH).

The ${ }^{13} \mathrm{CNMR}$ ligand (A3) spectrum displayed the $\mathrm{CH}_{3}-\mathrm{C}=$ group as the signal at 10.12 ppm and $\mathrm{CH}_{3}-\mathrm{N}=$ group at $33.85 \mathrm{ppm}$, also, the peak of (=C-N) group showed at $106.14 \mathrm{ppm}$. The other peaks of aromatic carbons resonance observed at 123.57-149.97 ppm. The signals at 151.17-154.26 ppm of ionic carbon $(\mathrm{C}=\mathrm{N})$ and $(\mathrm{N}-\mathrm{C}=)$ as functional groups. Also, the signal of carboxylic carbon is displayed at 165.64 .

\section{Molar conductivity}

The molar conductivities of the compounds had measured at room temperature under $10^{-3} \mathrm{M}$ of their ethanolic solution. The molar conductivity values of (S1), (S2), (S3) and (S4) under investigation are found to be at $(72,76,83,87$, and $89 \mathrm{ohm}^{-1} \mathrm{~cm}^{2} \mathrm{~mol}^{-1}$ ), correspondingly. It is clear from these data that the compounds are ionic and they are of $1: 2$ electrolytes in type ${ }^{20}$. In addition, the conductance data are low for (S5) and (S6) complexes lie at(1.2 and $2.9 \mathrm{ohm}^{-1} \mathrm{~cm}^{2} \mathrm{~mol}^{-1}$ ) support their non-electro nature of the compounds.

\section{Biological activities}

The Biological activity In vitro of created Schiff base ligands and their resultant metal compounds on tested two bacteria $S$. aureus and $E$. coli and dual fungi $A$.niger and $C$. albicans was done. Each particular components presented perfect biological effectiveness with microorganisms. The biological effectiveness of all selected compounds were liken with the norm fungicide and bactericide. The mixed complexes have mild effectiveness were liken to the typical degrees. Nevertheless, all compounds are more effective as compared with their relevant ligands. It is, on the other hand, identified that chelation is likely to make Schiff bases have more influential and strong bactereostatic agents, hence constraining the growing fungi and bacteria more than the parent ligands. It is doubted that agents like dipole, conductivity, moment solubility and cell penetrability technicality (affected by the existence of metallic ions) can be probable causes intensification in efficiency. The diameter in $(\mathrm{mm})$ of the repression domains are summarized in Tables 1 and 2 .

Table 1: Antibacterial screening data for the ligands and their compounds

\begin{tabular}{|c|c|c|c|c|c|c|c|c|c|c|c|c|}
\hline \multirow[t]{2}{*}{ Compound } & \multicolumn{2}{|c|}{$\begin{array}{l}\text { E. coli } \\
\text { ter of inhibition } \\
\text { one }(\mathrm{mm})\end{array}$} & \multicolumn{3}{|c|}{$\%$ Activity index } & \multicolumn{4}{|c|}{$\begin{array}{l}\text { S.aureus } \\
\text { Diameter of inhibition } \\
\text { zone }(\mathrm{mm})\end{array}$} & \multicolumn{3}{|c|}{$\begin{array}{c}\% \text { Activity } \\
\text { index }\end{array}$} \\
\hline & 25 & 50 & 100 & 25 & 50 & 100 & 25 & 50 & 100 & 25 & 50 & 100 \\
\hline$[\mathrm{A} 1]$ & 10 & 12 & 15 & 49 & 55 & 59 & 9 & 11 & 15 & 52 & 57 & 59 \\
\hline [A2] & 9 & 11 & 14 & 50 & 54 & 57 & 10 & 12 & 16 & 53 & 58 & 60 \\
\hline [A3] & 11 & 13 & 16 & 50 & 56 & 60 & 12 & 14 & 18 & 55 & 59 & 61 \\
\hline [S1] & 17 & 20 & 25 & 78 & 84 & 90 & 15 & 19 & 21 & 87 & 90 & 93 \\
\hline [S2] & 15 & 19 & 21 & 80 & 84 & 88 & 16 & 20 & 22 & 81 & 85 & 87 \\
\hline [S3] & 18 & 22 & 27 & 81 & 86 & 92 & 18 & 22 & 24 & 92 & 98 & 101 \\
\hline [S4 ] & 19 & 24 & 30 & 84 & 87 & 95 & 20 & 24 & 27 & 97 & 104 & 106 \\
\hline [S5] & 20 & 25 & 31 & 82 & 87 & 91 & 19 & 25 & 28 & 82 & 103 & 105 \\
\hline [S6] & 21 & 26 & 28 & 82 & 86 & 92 & 20 & 26 & 30 & 88 & 104 & 107 \\
\hline Streptomycin (Standard) & 21 & 22 & 26 & 100 & 100 & 100 & 18 & 22 & 26 & 100 & 100 & 100 \\
\hline
\end{tabular}


Table 2: Antifungal screening data for the ligands and their complexes

\begin{tabular}{lcccccc}
\hline Compound & \multicolumn{3}{c}{$\begin{array}{c}\text { Diameter of inhibition zone }(\mathrm{mm}) ; \\
\text { A. niger }\end{array}$} \\
& \multicolumn{7}{c}{ Concentration in ppm } \\
C. albicans
\end{tabular}

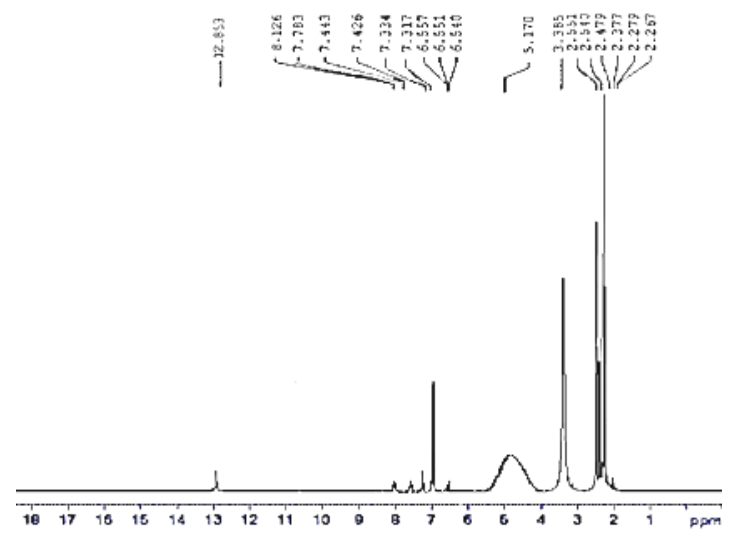

Fig. 1. ${ }^{1} \mathrm{H}-\mathrm{NMR}$ spectrum of the Ligand( $\left(L^{1}\right)$

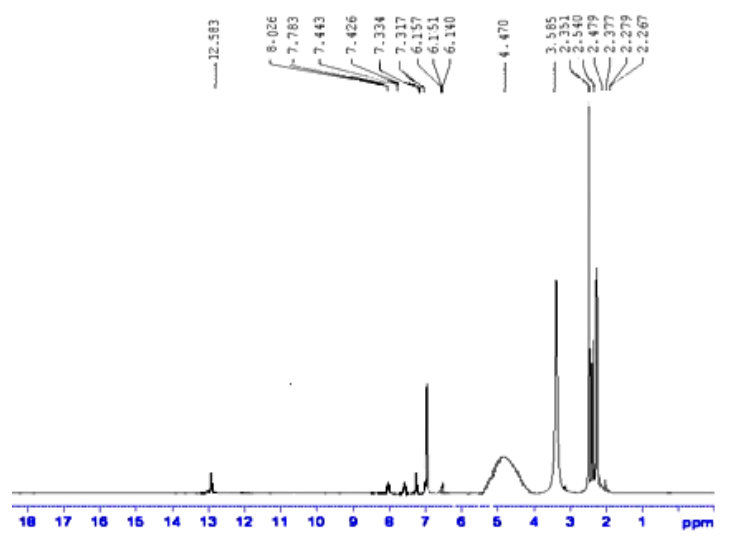

Fig. 3. ${ }^{1} \mathrm{H}-\mathrm{NMR}$ spectrum of the Ligand $\left(\mathrm{L}^{2}\right)$

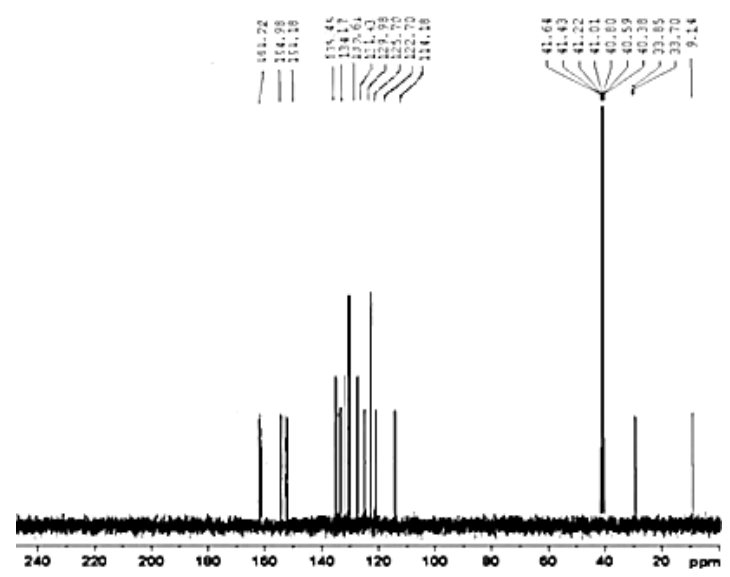

Fig. $2 .{ }^{13} \mathrm{C}-\mathrm{NMR}$ spectrum of the Ligand( $\left.\mathrm{L}^{1}\right)$

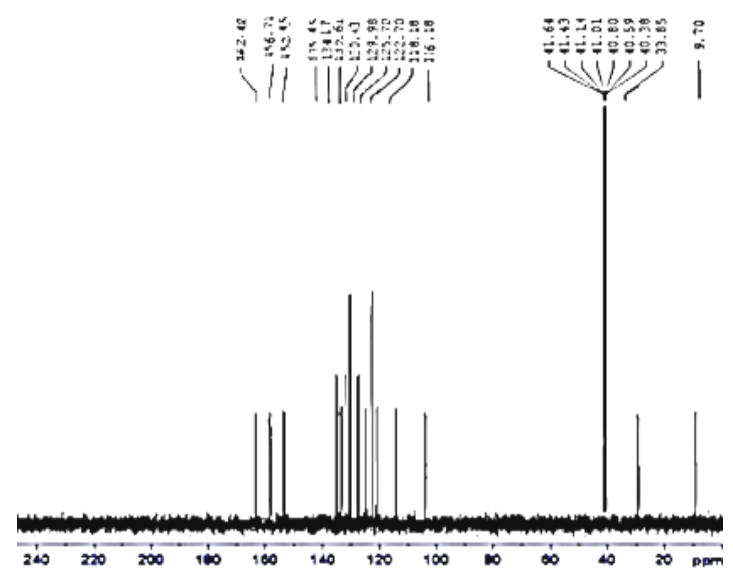

Fig. 4. ${ }^{13} \mathrm{C}$-NMR spectrum of the Ligand $\left(\mathrm{L}^{2}\right)$ 


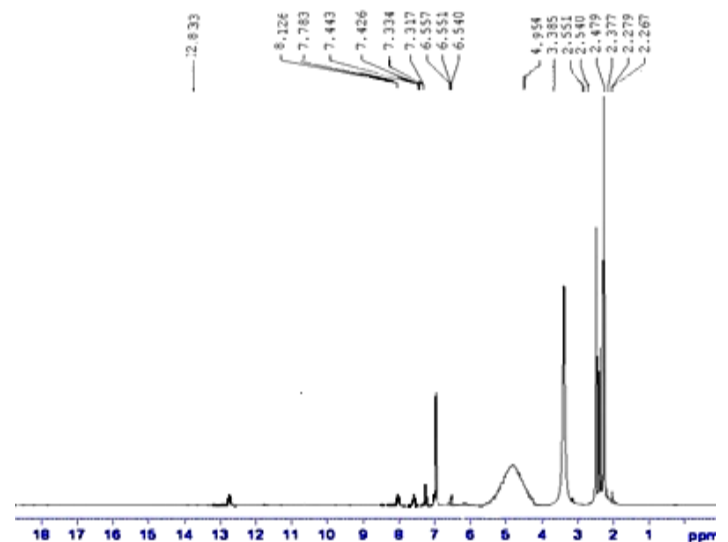

Fig. 5. ${ }^{1} \mathrm{H}-\mathrm{NMR}$ spectrum of the Ligand $\left(\mathrm{L}^{3}\right)$ CONCLUSION

From the UV-Vis ${ }^{1} \mathrm{H}$ and ${ }^{13} \mathrm{CNMR}$ and IR spectra, elemental analysis, molar conductivity, and magnetic values, it is imaginable to measure the kind of chelation of the ligand in their mixed complexes. Depended on these values, octahedral arrangement has been signified as (S1) (S2) (S3) and (S4) complexes except (S5), (S6) complexes are assigned a square planar arrangement.

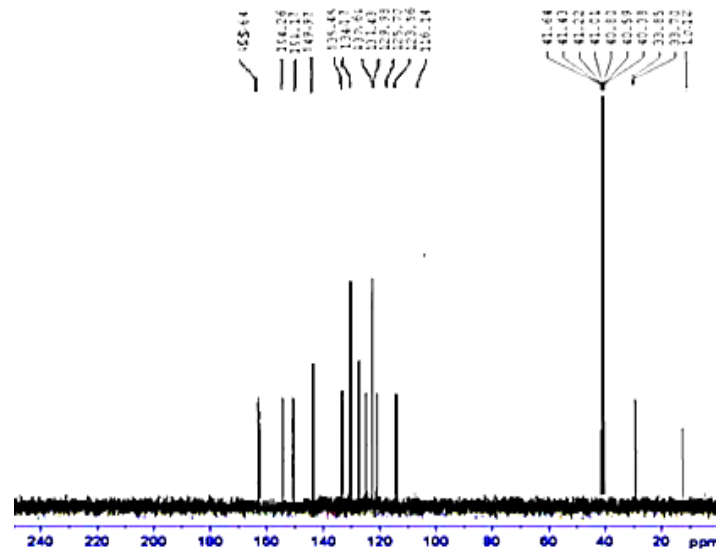

Fig. $6 .{ }^{13} \mathrm{C}-\mathrm{NMR}$ spectrum of the Ligand $\left(\mathrm{L}^{3}\right)$

The biological activity of these metal compounds with bacteria; $E$. coli and $S$. aureus, and fungi $A$. niger and $C$. albicans was investigated. From the results, it is found that the mixed complexes have been patterned for the biological testing mostly regarding the mixed compounds versus the bacteria and fungi, also, and may be concluded that the metal complexes are effective both for bacteria and fungi also.

\section{REFERENCES}

1. Dhar, D. N.; Taploo, C.L., J. Sci.Ind. Res., 1982, 41(8), 501-506.

2. Maria, D.M.C.; Ribeiro, D.; Jorge, M.G.; Ana, L.R.S.; Paula, C.F.C.; Bernd, S., J. Mol. Catal. A: Chem., 2004, 224, 207-212.

3. Cotton, A.F.; Wilkenson, G., ${ }^{5 \text { th }}$ Edition 1988, John Wiley and Sons USA., 37-50.

4. Hassan, K.; Salehzadeh, H.S.; Parish, R.V., J. Molecules., 2002, 7, 140-144.

5. Kirshener, Wei S.Y.K., Francis, D.; Bergman, J.H., Anticancer and potential antiviral activity of complex inorganic compounds, $J$. Med. Chem., 1966, 9, 369-372.

6. Joana, C.; Carolina ,M.; Sofia, S.; Pedro, V. B. ; Alexandra, R. F., Ann. Med. Chem. Res., 2015, 1(2), 1010, 1-5.

7. Yu, R.; Ling, Z., Cheng-He, Z. ; Rong-Xia, G., Med. chem., 2014, 4(9), 640-662.

8. Kostova, I.; Raleva ,S.; Genova, P. ; Argirova, R., Bio. Chem., \& Appli., 2006, 5, 1-9

9. Lever A.B.P., Elsevier 1984, New York

10. Kojima, M.; Taguchi, H.; Tsuchimoto, M.; Nakajima, K., Coord. Chem.Rev., 2003,237, 183-196.

11. Long, N.J., Chem. Int. ${ }^{1 \text { th }}$ Edition 1995., 34, 21.

12. Cusumano, M.; Messina, M.A.; Nicolo F., Pietro M.L.D., Rotondo A., and Rotondo, E.,
Eur. J. Inorg. Chem., 2004, 47, 10-4717.

13. Avaji ,P.G.; Kumar, C.H.V., Patil ,S. A, Shivananda, K. N.; Nagaraju, C., Eur. J. Med. Chem., doi: 10.101.6/j.ejmech. 03.032, 2009.

14. Canpolat, E. and Kaya, M., J. Coord. Chem., 2004, 123, 413-425

15. RaheemR K.; Fayad A.A., Sci. Revs. Chem., Commun., 2016, 6(3), 37-52.

16. Chakravarty, A.R., Nreddy, A. P., Santra, B.K.; Thomas, A.M., J. Indian. Chem. Sci., 2002, 114, 319-401.

17. Himaja ,M.; Kailash, R.; Anish, K. V.;Ramana, M.V. ; Karigar, A. A., J. Pham. \& Sci. Innv.,2012, 1(1)67-70.

18. Raheem, R. K.; Tawfiq, M.T., Eur. Chem. Bull., 2016, 5(11), 470-478.

19. Ferreira, E.I.; Tavares, L.C., Bioorg. Med. Chem., 2002, 10, 557-560.

20. Anand, K; Gupta, S.; Barhate, V.D,Res. J. of Pharma.Bio. and Chem. Sci., 2012, 3(3) $10103-10126$.

21. Raman, N. ; Sobha , S.; Mitu, L.; J. Saudi Chem. Soc., 2013, 17, 151-159.

22. Sampath, K. ; Karthik, K.; Sivahari R.;Rasayan J. Chem., 2017, 10(4), 1184-1188.

23. Prakash, V.; Suresh, M. S.,Res. J. Phar., Bio. \& Chem.Sci., 2013, 4(4), 1536-1550. 